\title{
ACUTE HAEMOLYTIC ANAEMIA FOLLOWING THE INGESTION OF PARA-DICHLOROBENZENE
}

BY

\author{
M. HALLOWELL \\ From the Children's Hospital, Birmingham
}

(RFCEIVED FOR PUBLICATION JULY 21, 1958)

Reports of cases of haemolytic anaemia after the ingestion of moth-balls are. scanty. Nash (1903) briefly records a case of a boy of 13 who developed black urine after eating a single moth-ball in mistake for a sweet, but no haematological data are given. Zuelzer and Apt (1949) describe the case histories of four young negro children who developed acute haemolytic anaemia and haemoglobinuria following the ingestion of moth-balls containing naphthalene. Gidron and Leurer (1956) report a girl of 16 who developed an acute haemolytic anaemia with haemoglobinuria after swallowing $6 \mathrm{~g}$. of naphthalene in an attempt to commit suicide. The following is a report of a child who developed an acute haemolytic anaemia with methaemoglobinuria after the ingestion of another demothing agent, para-dichlorobenzene.

\section{Case History}

Paul S., aged 3 years, was admitted to the Birmingham Children's Hospital on March 9, 1958, with a history of a cough for a few days. The day before admission he seemed listless, his sclera became yellow and the urine he passed was almost black in colour. There was no family history of jaundice or anaemia. On examination he was jaundiced and his mucous membranes were pale. His temperature was $97^{\circ} \mathrm{F}$., pulse rate 100 per minute and blood pressure 95/70. The liver and spleen were not enlarged. He had a dry cough, but the lung fields were clear. A blood count showed haemoglobin $56 \%$ $(8.25 \mathrm{~g} . / 100 \mathrm{ml}$.), reticulocytes $5 \%$, leucocytes 14,700 , predominantly granulocytes. The blood group was $\mathrm{O}$, Rhesus positive, the serum bilirubin $2.6 \mathrm{mg}$. $\%$ and the blood urea $53 \mathrm{mg} . \%$. As he had not passed urine for 15 hours before admission he was catheterized and $4 \mathrm{oz}$. of dark, port wine coloured urine were obtained. Spectroscopic examination showed the characteristic bands of methaemoglobin and Schumm's test for methaemalbumen was positive. On microscopy there were no red cells.

The next day the Coombs test was carried out by three independent haematologists and reported by each as being negative. The blood was fully investigated for the presence of antibodies but none was found. There were no cold agglutinins. A chest radiograph was normal. His haemoglobin had now fallen to $36 \%(5.4 \mathrm{~g} . / 100 \mathrm{ml}$.), his pulse rate had risen to 150 per minute and his blood pressure had dropped to $80 / 50$. He was transfused with one pint of blood, which produced a brief and transient increase in the methaemoglobinuria, and then given intravenous fluids for the succeeding 36 hours.

During the third day in hospital the methaemoglobinuria ceased. His urinary output was markedly reduced during the first two days but subsequently improved and by the sixth day his blood urea had fallen to $17 \mathrm{mg}$. \%.

When the haemolytic phase had subsided the following investigations were carried out. Red cell fragility : haemolysis commenced at $0.45 \%$ and was complete at $0 \cdot 32 \%$. No sickling of the red cells was demonstrable and no target cells were seen. The Wasserman and Kahn reactions were negative.

Following the blood transfusion his haemoglobin rose to $74 \%(11.0 \mathrm{~g} . / 100 \mathrm{ml}$.) but gradually fell over the next five days to $53 \%(7.8 \mathrm{~g} . / 100 \mathrm{ml}$.). On the seventh day in hospital his reticulocyte count reached $17 \%$. He was discharged home on March 26, 1958, on an oral iron preparation. When last seen on April 14, 1958, he was clinically well and his haemoglobin had risen to $78 \%$ $(11.6 \mathrm{~g} . / 100 \mathrm{ml}$.).

\section{Discussion}

On admission it was considered that this child was probably suffering from an acute haemolytic anaemia secondary to a virus pneumonia, but the negative Coombs test and absence of cold agglutinins in the blood made this unlikely. Enquiries were then directed to poisons and drugs. The family doctor had not prescribed any medicine other than Mist. ipecac et opii pro infant., but his interview with the mother revealed that the child had been playing with a small canister labelled 'Demothing Crystals'. These crystals, which contain para-dichlorobenzene had been given away with a vacuum cleaner which the mother had purchased some months ago. His mother said that during the four to five days before the onset of jaundice and methaemoglobinuria she 
had seen him playing with the crystals, sprinkling them over the floor, spreading them out with his hands, then replacing them one by one in the canister, all the time playing with a comforter in and out of his mouth.

The first specimen of urine was examined biochemically. After precipitation of the methaemoglobin the deproteinized urine gave an intense naphthoresorcinol reaction and did not contain any inorganic sulphate. By paper chromatography, spots suggestive of four abnormal phenols were observed. At this time appropriate reference compounds for their identification were not available.

The other specimens of the dark urine passed during the first three days in hospital were pooled and kept in the refrigerator for six days. By this time the colour had changed to a very dark red and spectroscopic examination no longer showed methaemoglobin; it had been reduced to haemoglobin.

Synthetic specimens of 2:5 dichlorophenol and 2:5 dichloroquinol were available at the end of the six days. A 24-hour specimen of urine collected when the child had practically recovered was used as a normal control. This specimen and the above mentioned pooled specimen of urine were hydrolyzed and examined for phenols by paper chromatography. The abnormal urine revealed traces of 2:5 dichloroquinol and at least two other phenols not present in the control, but 2:5 dichlorophenol was not found.

Para-dichlorobenzene metabolism has been studied in rabbits by Azouz, Parke and Williams (1955). The chief metabolites to be expected after the ingestion of para-dichlorobenzene are 2:5 dichlorophenol and 2:5 dichloroquinol. Phenols and quinols are conjugated with glucuronic acid and sulphuric acid and then excreted. The finding in this case of an intense naphthoresorcinol reaction and the conversion of practically all the inorganic sulphate into ethereal sulphate is in keeping with the formation of these metabolites. This, together with the finding of traces of 2:5 dichloroquinol and other abnormal phenols is strong presumptive evidence that the child must have ingested some of the para-dichlorobenzene crystals.

The urine was several days old at the time of the second examination and the methaemoglobin had been reduced; 2:5 dichloroquinol may have been responsible for this reduction, and if this were so it would explain the fact that only traces were present.

According to Browning (1953) the chief toxic effects of para-dichlorobenzene in animals are liver and kidney damage. No toxic effects have been reported in man. Methaemoglobin formation has not been observed in the rabbit, but this animal does not form methaemoglobin as readily as man.

Benzene itself is a recognized haemolytic agent. Erf and Rhoads (1939) described the case histories of nine industrial workers who were exposed to benzene fumes. They developed a chronic haemolytic anaemia. Nabarro (1948) described a case of acute haemolytic anaemia occurring six days after the ingestion of another benzene compound mononitrobenzene. He stated that haemolysis is found in all moderately severe cases of mononitrobenzene poisoning.

Demothing crystals which contain para-dichlorobenzene are freely available to the general public and are sold in vast quantities each year, particularly during the spring season. The importance of keeping them out of the reach of children cannot be over emphasized.

\section{Summary}

A case of acute haemolytic anaemia occurring in a child of 3 years after the ingestion of paradichlorobenzene is reported. The haemolysis was severe and necessitated a blood transfusion. Complete recovery occurred. The biochemical findings in the urine are fully reported and the metabolism of para-dichlorobenzene is discussed.

My thanks are due to Professor J. M. Smellie for permission to publish this case and for his advice and also to Professor J. M. Webster, to Dr. W. Weiner, Dr. K. B. Rogers and Dr. J. N. M. Chalmers for the haematological investigations, to Dr. G. D. H. McQuitty the family doctor, and to Dr. W. V. Thorpe who carried out the biochemical studies.

\section{REFERENCES} Azouz, W. M., Parke, D. V. and Williams, R. T. (1955). Biochem J.,

Browning, E. (1953). Toxicity of Industrial Organic Solvents, p. 189. Med. Res. Coun. Industr. Hlth Res. Bd. Rep. No. 80 (rev. ed.). H.M.S.O., London.

Erf, L. A. and Rhoads, C. P. (1939). J. industr. Hyg., 21, 421.

Gidron, E. and Leurer, J. (1956). Lancet, 1, 228.

Nabarro, J. D. N. (1948). Brit. med. J., 1, 929.

Nash, L. F. (1903). Ibid., 1, 251.

Zuelzer, W. W. and Apt, L. (1949). J. Amer. med. Ass., 141, 185. 